Game Production Studies 



\title{
Game Production Studies
}

\author{
Edited by \\ Olli Sotamaa \\ and Jan Švelch
}


The publication of this book is made possible by Academy of Finland project Centre of Excellence in Game Culture Studies (CoE-GameCult, 312395).

Cover image: Jana Kilianová

Cover design: Coördesign, Leiden

Lay-out: Crius Group, Hulshout

$\begin{array}{ll}\text { ISBN } & 978 \text { 94 6372 5439 } \\ \text { e-ISBN } & 978 \text { 90 } 48551736 \\ \text { DOI } & 10.5117 / 9789463725439 \\ \text { NUR } & 670\end{array}$

\section{(C) $(1) \Theta \Theta$}

Creative Commons License CC BY NC ND

(http://creativecommons.org/licenses/by-nc-nd/3.o)

@ O. Sotamaa and J. Švelch / Amsterdam University Press B.V., Amsterdam 2021

Some rights reserved. Without limiting the rights under copyright reserved above, any part of this book may be reproduced, stored in or introduced into a retrieval system, or transmitted, in any form or by any means (electronic, mechanical, photocopying, recording or otherwise).

Every effort has been made to obtain permission to use all copyrighted illustrations reproduced in this book. Nonetheless, whosoever believes to have rights to this material is advised to contact the publisher. 